\title{
RESIDUAL LIFE OF REPAIR WELDED JOINTS IN PIPELINES MADE OF 13HMF AFTER USE FOR THE DESIGN OPERATING TIME
}

This paper presents the results of material tests of repair welded joints carried out for samples of materials taken from high pressure steam pipelines after over 200,000 operating hours in creep conditions, made of the 13HMF steel (14MoV6-3). The aim of the study was to assess the mechanical properties and changes in the structure of repair welded joints (new material + material after use), including the original material, heat affected zone and the weld, occurring as a result of the welding process and heat treatment after welding.

\section{TRWAŁOŚĆ RESZTKOWA NAPRAWCZYCH ZŁĄCZY SPAWANYCH NA RUROCIĄGACH WYKONANYCH Z 13HMF PO PRZEPRACOWANIU OBLICZENIOWEGO CZASU PRACY}

\begin{abstract}
W niniejszym opracowaniu zaprezentowano wyniki badań materiałowych przykładowych naprawczych złaczy spawanych wykonanych na próbkach materiałów pobranych z rurociagów pary wysokoprężnej po przepracowaniu 200 tysięcy godzin pracy w warunkach petzania, wykonanych ze stali 13HMF (14MoV6-3). Celem badań byta ocena właściwości mechanicznych oraz zmian struktury naprawczych złaczy spawanych (materiat nowy + materiat po eksploatacji) obejmujacych materiat rodzimy, strefe wpływu ciepła $i$ spoine, zachodzacych na skutek procesu spawania i przeprowadzonej obróbki cieplnej po spawaniu.
\end{abstract}

Stowa kluczowe: pełzanie, degradacja, naprawcze złacza spawane, stal Cr-Mo-V, trwałość resztkowa

\section{INTRODUCTION}

In the power industry, steam pipelines that are being used for a long time are repaired or modernised. These procedures are the result of failure, material damage or insufficient technical condition of the component. They also result from the necessity to change the course or expand the installation. In the case of surface defects, repairs are made by grinding until the indication disappears. However, if repair by grinding is not possible due to the size of the defect or condition of the material, it is necessary to replace the entire component or its fragment. In such case, the repair involves the necessity to repair welded joints. Safety reasons make it necessary to know the strength parameters not only of the used materials, but also of the welded joints themselves. The welding process itself and the heat treatment of the joint may cause accelerated degradation of the materials of the welded components. Therefore, planning such works should take into account the actual properties of the welded materials - both those previously used and the materials as delivered and the impact of the welding process and heat treatment on their microstructure.

\section{MATERIAL AND METHODOLOGY}

The used pipeline materials were taken from fresh steam pipelines operating beyond the design operating time. The sections selected and taken for destructive testing were characterised by the highest degree of wear estimated for individual pipelines. They were taken from the areas with the highest stress indicators estimated on the basis of the stress distribution analysis with regard to the actual operation of the suspension and support system. A comparison of the tested pipeline sections is presented in Table 1.

Samples made of 14MoV6-3 taken from the provided certified pipe fragment with a diameter and thickness corresponding to the diameters and thicknesses of the used pipes were applied as the new material. A WMoVSi wire and an EMoVB42H5 electrode were used as additional materials for welding per EN ISO 21952-A and EN ISO 3580-A respectively. The weld metal obtained from the above-mentioned materials, after the required heat treatment at an annealing temperature of $710 \pm 10^{\circ} \mathrm{C}$, has an appropriate elongation $\mathrm{A}$ of around $22 \%$ and a KCV impact strength at room temperature of $200 \mathrm{~J}$. 
Table 1. Material of primary steam pipelines made of the 13HMF steel with different microstructure state and degree of wear after long-term use in creep conditions, selected on the basis of destructive testing

Tabela 1. Wytypowany na podstawie badań niszczących materiał rurociągów pary pierwotnej ze stali 13HMF o różnym stanie mikrostruktury i stopniu wyczerpania po długotrwałej eksploatacji w warunkach pełzania

\begin{tabular}{|c|c|c|c|c|c|}
\hline No. & $\begin{array}{c}\text { Identification } \\
\text { Steel grade }\end{array}$ & $\begin{array}{c}\text { Pressure } \\
\boldsymbol{\sigma}_{\boldsymbol{r}}[\mathbf{M P a}]\end{array}$ & $\begin{array}{c}\text { Steel temperature } \\
\boldsymbol{T}_{\boldsymbol{r}}\left[^{\circ} \mathbf{C}\right]\end{array}$ & $\begin{array}{c}\text { Material condition } \\
\text { Class } \\
\text { Degree of wear }\end{array}$ & $\begin{array}{c}\text { Time of previous use } \\
\text { CLASS } 1\end{array}$ \\
\hline 1 & $\begin{array}{c}\text { Sample } 1 \\
13 \mathrm{HMF}\end{array}$ & 14 & 540 & $0.2-0.3$ \\
\hline 2 & $\begin{array}{c}\text { Sample } 2 \\
13 \mathrm{HMF}\end{array}$ & 14 & 540 & CLASS $2 / 3$ \\
0.4
\end{tabular}

Table 2. Chemical composition follow-up

Tabela 2. Analiza kontrolna składu chemicznego

\begin{tabular}{|c|c|c|c|c|c|c|c|c|c|c|}
\hline \multirow{2}{*}{ Material type } & \multicolumn{9}{|c|}{ Element content [wt \%] } \\
\cline { 2 - 10 } & $\mathbf{C}$ & Mn & Si & F & S & Cu & \multicolumn{1}{c|}{ Cr } & Ni & Mo & other \\
\hline $\begin{array}{c}\text { PN-75/H-84024 } \\
\text { standard } \\
\text { 13HMF }\end{array}$ & 0.100 .18 & 0.400 .70 & 0.150 .35 & max. 0.04 & max. 0.04 & max. 0.25 & 0.300 .60 & max. 0.30 & 0.500 .65 & $\begin{array}{c}\text { V } 0.22-0.35 \\
\text { Al max. } 0.02\end{array}$ \\
\hline $\begin{array}{c}\text { 13HMF } \\
\text { des. 1 }\end{array}$ & 0.15 & 0.52 & 0.26 & 0.012 & 0.012 & 0.13 & 0.51 & 0.16 & 0.59 & V 0.29 \\
\hline $\begin{array}{c}\text { 13HMF } \\
\text { des. 2 }\end{array}$ & 0.12 & 0.52 & 0.29 & 0.018 & 0.023 & 0.056 & 0.54 & 0.14 & 0.56 & V 0.32 \\
\hline
\end{tabular}

The study included:

- examination of structure using a scanning electron microscope

- testing strength properties at room temperature and elevated temperature close to the operating temperature

- impact strength tests to determine the brittle state transition temperature

- shortened creep tests to determine the available residual life, which is the time of safe use in the assumed parameters of further operation.

\section{METALLOGRAPHIC STUDIES}

The images of microstructures along with the classification of the wear rate of bainitic areas, precipitation processes and damage processes are shown in Figure 1 for the joint made using the material designated as " 1 ", and Figure 2 for the joint with material " 2 ". The results of metallographic studies for both joints are presented in Table 3.

In general, the degree of wear of the structure of the tested materials was estimated at about $0.2-0.3$ for the original material of sample number 1 and about 0.4 for the original material of sample number 2 (according to the IMŻ classification tables). For new materials in both tested samples, the structure was classified as a degree of wear equal to 0 . No discontinuities and micro-cracks were found in the structure of any zone of both tested joints. No initiation of internal damage processes, which was not previously found during the research with the use of matrix replicas observed in the scanning electron microscope, was found in the tested material.

\section{INVESTIGATION OF MECHANICAL PROPERTIES}

The results of strength tests obtained in a static tensile test were collected and included in Table 4 in comparison with the minimum results required by the standard for the used steels and their equivalent.

The tested properties of the materials as delivered meet the requirements of EN 10216-2:2014 for the used 14MoV6-3 material. The results of yield strength of the used materials obtained for room temperature are lower than the minimum requirements of the $\mathrm{PN}-75 / \mathrm{H}-84024$ standard, i.e. the requirements for the used material applicable at the time of manufacture. The above does not mean, however, that the tested material is unsuitable for its further use. Steam pipelines components operating under creep conditions are designed based on the values of permissible stress $k$ taking into account the average time-related creep strength $R_{z / t / T}$ or the creep limit $R_{x / t / T}$ to the design operating time. The obtained results of the actual yield strength at elevated temperature, on the other hand, are higher than the minimum requirements.

The value of yield strength results for room temperature and brittle transition temperature are important from the point of view of the continued operation of the installation - based on them, it is necessary to verify and follow the heating and cooling rates of the pipeline and the conditions for conducting pressure tests. The stresses created at these stages may cause damage or destruction of the installation if the admissible values are exceeded.

The impact energy determined for the used materials is significantly lower than for materials as delivered and does not meet the required $27 \mathrm{~J}$ at $20^{\circ} \mathrm{C}$ criterion. Other joint zones meet this requirement.

In both cases, the material's brittle state transition temperature determined in the impact test was positive and amounted to about $50^{\circ} \mathrm{C}$ for the original 

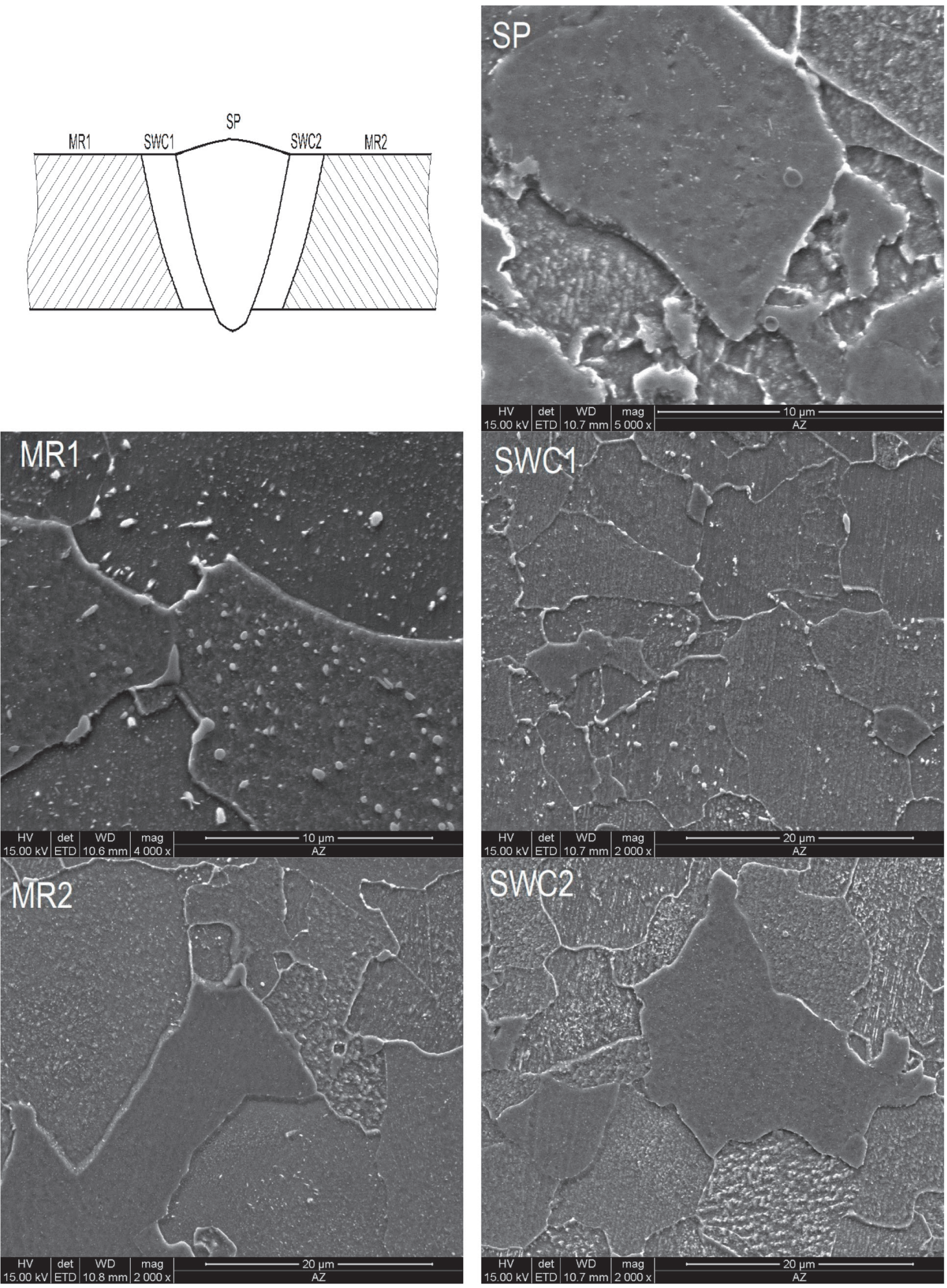

Fig. 1. Microstructure of individual zones of repair joint No. 1 - made by joining the material used for 216,000 operating hours (OM1) with the new material as delivered (MR2)

Rys. 1. Mikrostruktura poszczególnych stref złącza naprawezego $\mathrm{nr} 1$ - wykonanego poprzez połączenie eksploatowanego materiału po 216000 godzinach pracy (MR1) z materiałem nowym w stanie dostawy (MR2) 

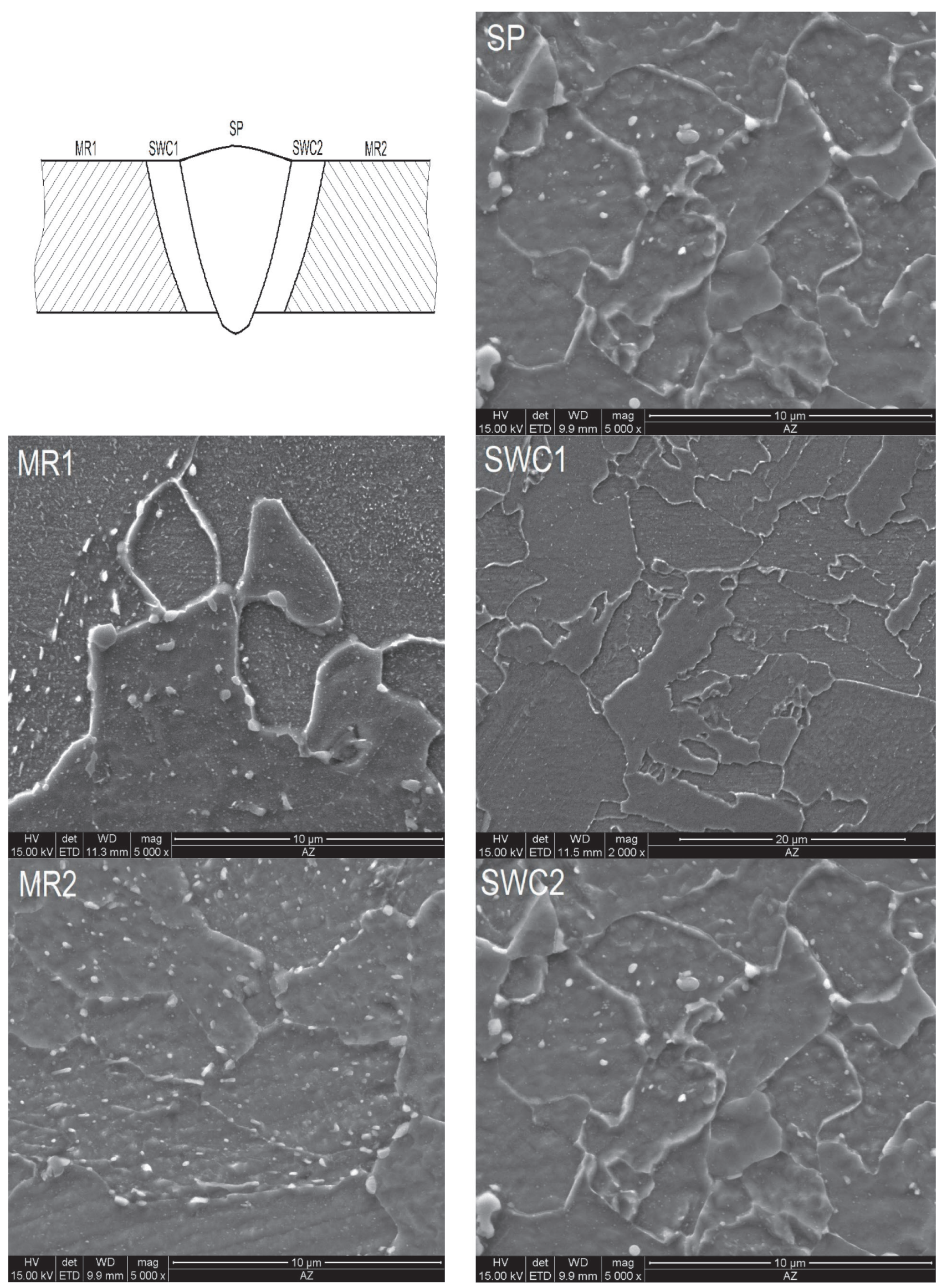

Fig. 2. Microstructure of individual zones of repair joint No. 2 - made by joining the material used for 240,000 operating hours (OM1) with the new material as delivered (MR2)

Rys. 2. Mikrostruktura poszczególnych stref złącza naprawezego $\mathrm{nr} 2$ - wykonanego poprzez połączenie eksploatowanego materiału po 240000 godzinach pracy (MR1) z materiałem nowym w stanie dostawy (MR2) 
Table 3. Evaluation of the results of the investigation of welded joint microstructures made by joining the materials used for 216,000 operating hours (joint 1) and 240,000 operating hours (joint 2) with the new material as delivered

Tabela 3. Ocena wyników badań mikrostruktury naprawczych połączeń spawanych wykonanych poprzez połączenie eksploatowanych materiałów po 216000 godzinach pracy (złącze 1) i 240000 godzinach pracy (złącze 2) z materiałem nowym w stanie dostawy

\begin{tabular}{|c|c|c|c|c|}
\hline \multirow[b]{2}{*}{ Material } & \multicolumn{2}{|l|}{ Joint 1} & \multicolumn{2}{|l|}{ Joint 2} \\
\hline & $\begin{array}{l}\text { Microstructure description } \\
\text { Material condition - degree of wear }\end{array}$ & $\begin{array}{l}\text { Hardness } \\
\text { HV10 }\end{array}$ & $\begin{array}{l}\text { Microstructure description } \\
\text { Material condition - degree of wear }\end{array}$ & $\begin{array}{l}\text { Hardness } \\
\text { HV10 }\end{array}$ \\
\hline $\begin{array}{l}\text { Original } \\
\text { material } \\
\text { OM1 }\end{array}$ & $\begin{array}{l}\text { Ferritic-bainitic structure. Coagulation } \\
\text { of most precipitates in bainitic areas. } \\
\text { Variation in the size of precipitates on } \\
\text { ferrite grain boundaries, some precipitates } \\
\text { of considerable size. Very fine, evenly } \\
\text { distributed precipitates inside ferrite } \\
\text { grains. } \\
\text { No discontinuities or micro-cracks } \\
\text { were observed in the structure. } \\
\text { No initiation of damage processes was } \\
\text { observed. } \\
\text { Bainitic areas: class I, precipitates: class a } \\
\text { Damage processes class 0 } \\
\text { class } 1 \text {, degree of WEAR: approx. } 0.2-0.3\end{array}$ & 159 & $\begin{array}{l}\text { Ferritic-bainitic structure with pearlite. } \\
\text { Significant coagulation of precipitates in } \\
\text { bainitic areas. Pearlitic areas with highly } \\
\text { fragmented cementite plaques, mostly } \\
\text { coagulated. Numerous precipitates of } \\
\text { various sizes on ferrite grain boundaries, } \\
\text { some quite significant. Very fine, evenly } \\
\text { distributed precipitates inside ferrite } \\
\text { grains. } \\
\text { No discontinuities or micro-cracks were } \\
\text { observed in the structure. } \\
\text { No initiation of damage processes was } \\
\text { observed. } \\
\text { Pearlite/bainite areas: class I/II, } \\
\text { precipitates: class a/b } \\
\text { Damage processes class } 0 \\
\text { class } 2 / 3 \text {, degree of WEAR: approx. } 0.4\end{array}$ & 145 \\
\hline $\begin{array}{l}\text { Heat affected } \\
\text { zone } \\
\text { HAZ1 }\end{array}$ & $\begin{array}{l}\text { Heat affected zone structure. } \\
\text { No discontinuities or micro-cracks } \\
\text { were observed in the structure. }\end{array}$ & 195 & $\begin{array}{l}\text { Heat affected zone structure. } \\
\text { No discontinuities or micro-cracks were } \\
\text { observed in the structure. }\end{array}$ & 166 \\
\hline $\begin{array}{l}\text { Weld } \\
\text { WL }\end{array}$ & $\begin{array}{l}\text { Structure of the weld's material. } \\
\text { No discontinuities or micro-cracks were } \\
\text { observed in the structure. }\end{array}$ & 245 & $\begin{array}{l}\text { Structure of the weld's material. } \\
\text { No discontinuities or micro-cracks were } \\
\text { observed in the structure. }\end{array}$ & 173 \\
\hline $\begin{array}{l}\text { Heat affected } \\
\text { zone } \\
\text { HAZ2 }\end{array}$ & $\begin{array}{l}\text { Heat affected zone structure. } \\
\text { No discontinuities or micro-cracks were } \\
\text { observed in the structure. }\end{array}$ & 220 & $\begin{array}{l}\text { Heat affected zone structure. } \\
\text { No discontinuities or micro-cracks were } \\
\text { observed in the structure. }\end{array}$ & 217 \\
\hline $\begin{array}{c}\text { Original } \\
\text { material } \\
\text { OM2 }\end{array}$ & $\begin{array}{l}\text { Ferritic-bainitic structure. Bainitic areas } \\
\text { typical for the tested steel in initial } \\
\text { condition. } \\
\text { Bainitic areas: class } 0 \text {, precipitates: class } 0 \\
\text { Damage processes: class } 0 \\
\text { class } 0 \text {, degree of WEAR: } 0\end{array}$ & 183 & $\begin{array}{l}\text { Ferritic-bainitic structure. Bainitic areas } \\
\text { typical for the tested steel in initial } \\
\text { condition. } \\
\text { Bainitic areas: class } 0 \text {, precipitates: class } 0 \\
\text { Damage processes: class } 0 \\
\text { class } 0 \text {, degree of WEAR: } 0\end{array}$ & 181 \\
\hline
\end{tabular}

Table 4. Results of the investigation of strength properties [13-15]

Tabela 4. Wyniki badań właściwości wytrzymałościowych [13-15]

\begin{tabular}{|c|c|c|c|c|c|c|}
\hline \multirow{3}{*}{$\begin{array}{l}\text { Component } \\
\text { name }\end{array}$} & \multirow{3}{*}{$\begin{array}{l}\text { Steel } \\
\text { grade }\end{array}$} & \multirow{3}{*}{ Section designation } & \multicolumn{4}{|c|}{ Strength properties } \\
\hline & & & $\boldsymbol{R}_{m}$ & $\boldsymbol{R}_{e}$ & $\boldsymbol{A}$ & $R_{p 0.2}^{500}$ \\
\hline & & & MPa & MPa & $\%$ & MPa \\
\hline 1 & 2 & 3 & 4 & 5 & 6 & 7 \\
\hline \multirow{2}{*}{ Joint 1} & $13 \mathrm{HMF}$ & des. OM1 & 517 & 303 & 29.7 & 218 \\
\hline & 14MoV6-3 & des. OM2 & 555 & 385 & 24.5 & 288 \\
\hline \multicolumn{2}{|c|}{$\begin{array}{l}\text { Circular homogeneous joint } \\
\text { steel 13HMF }\end{array}$} & des. WJ1 & 510 & 321 & 16.0 & 256 \\
\hline \multirow{2}{*}{ Joint 2} & $13 \mathrm{HMF}$ & des. OM1 & 518 & 291 & 27.0 & 209 \\
\hline & 14MoV6-3 & des. OM2 & 555 & 385 & 24.5 & 288 \\
\hline \multicolumn{2}{|c|}{$\begin{array}{l}\text { Circular homogeneous joint } \\
\text { steel 13HMF }\end{array}$} & des. WJ1 & 510 & 311 & 17.0 & 227 \\
\hline \multicolumn{3}{|c|}{$\begin{array}{l}\text { REQUIREMENTS FOR STEEL 14MoV6-3 } \\
\text { IN INITIAL CONDITION PER EN 10216-2:2014 }\end{array}$} & $460-610$ & $\min .320$ & $\min .18$ & $\min .200$ \\
\hline \multicolumn{3}{|c|}{$\begin{array}{l}\text { REQUIREMENTS FOR STEEL 13HMF } \\
\text { IN INITIAL CONDITION PER PN-75/H-84024 }\end{array}$} & $490-690$ & $\min .392$ & $\min .18$ & $\min .206$ \\
\hline
\end{tabular}


Table 5. Results of impact strength tests of the components

Tabela 5. Wyniki badań udarności elementów

\begin{tabular}{|c|c|c|c|c|c|c|c|c|}
\hline \multirow{3}{*}{$\begin{array}{l}\text { Component } \\
\text { name }\end{array}$} & \multirow{3}{*}{$\begin{array}{c}\text { Section } \\
\text { designation }\end{array}$} & \multicolumn{7}{|c|}{ Impact energy KV [J] } \\
\hline & & \multicolumn{7}{|c|}{ Testing temperature $\left[{ }^{\circ} \mathrm{C}\right]$} \\
\hline & & -20 & -0 & 20 & 40 & 60 & 80 & 100 \\
\hline \multirow{5}{*}{$\begin{array}{c}\text { Welded joint des. } 1 \\
\text { steel 13HMF/14MoV6-3 }\end{array}$} & des. OM1 & 4 & 6 & 17 & 21 & 48 & 68 & 74 \\
\hline & des. OM2 (new) & 12 & 24 & 41 & 154 & - & - & - \\
\hline & des. HAZ2 (new) & 15 & 31 & 51 & 148 & - & - & - \\
\hline & des. HAZ1 (old) & 20 & 25 & 65 & 85 & - & - & - \\
\hline & des. weld & 8 & 10 & 35 & 55 & 95 & - & \\
\hline \multirow{5}{*}{$\begin{array}{c}\text { Welded joint des. } 2 \\
\text { steel 13HMF/14MoV6-3 }\end{array}$} & des. OM1 & 4 & 6 & 10 & 19 & 35 & 75 & 141 \\
\hline & des. OM2 (new) & 12 & 24 & 41 & 154 & - & - & - \\
\hline & des. HAZ2 (new) & 20 & 30 & 55 & 134 & - & - & - \\
\hline & des. HAZ1 (old) & 10 & 28 & 45 & 65 & - & - & - \\
\hline & des. weld & 10 & 15 & 41 & 58 & 90 & - & \\
\hline
\end{tabular}

materials after use and about $15-20^{\circ} \mathrm{C}$ for the welds (Figures 3-4). With the level of tensile strength and yield strength determined for the tested samples, the possible pressure test of the pipeline may only have the character of a leak test, but it may not be a strength test of the pipeline. The positive temperature of transition into brittle state requires, however, strict adherence to the required conditions of start-ups and stops.

\section{SHORTENED CREEP TESTS}

The decisive indicator of the suitability of high pressure steam pipeline materials is creep strength. It is of great importance especially in the case of installations operated above the design working time. Determination of residual life through accelerated creep tests provides knowledge about the real possibilities of further use of a given material and allows to determine the time of further safe use of the material under specific conditions.

Shortened creep tests were carried out to determine the residual life of the analysed welded joints. The tests were carried out at a constant stress level, corresponding to the assumed operating stress $\left(\sigma_{0}=\sigma_{r}=\right.$ const $)$ and different temperature level, higher than the assumed operating temperature $\left(T_{b}>T_{r}\right)$, allowing to determine the residual life and available residual life for operating parameters of further use. The dependencies of time to break in shortened creep tests of the tested materials are graphically presented in Figures 5-6 in the form of the relation $\log t_{z}=\mathrm{f}\left(T_{b}\right)$ at $\sigma_{b 1} \approx \sigma_{r}$ and $\sigma_{b 2} \approx \sigma_{r+10^{\circ} \mathrm{C}}$ presented in Table 6 .

When analysing the results obtained in the shortened creep tests, it can be concluded that the welding process and heat treatment after welding caused much greater degradation in the case of the welded joint made using material 2 (after 240,000 operating hours)

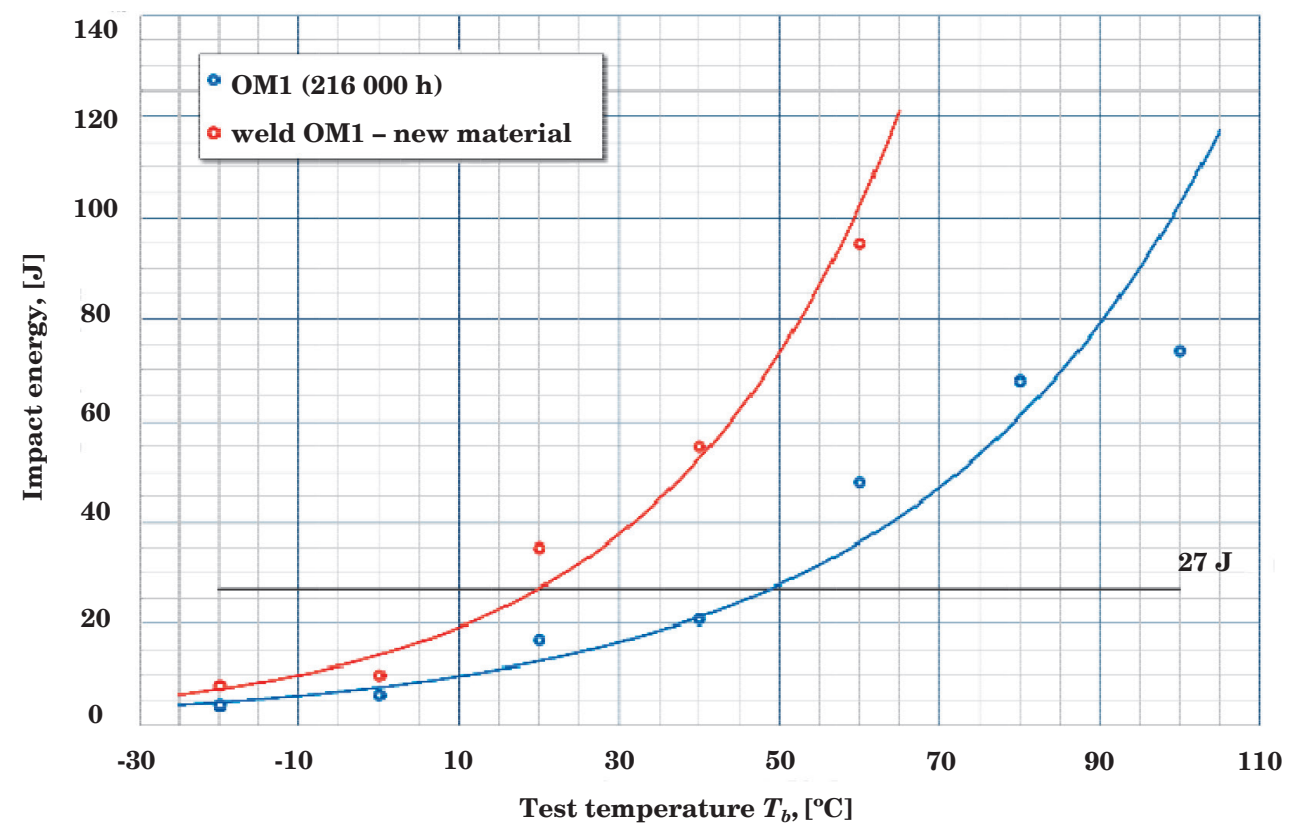

Fig. 3. Determination of the brittle state transition temperature for welded joint components (OM1 and W) - sample 1 after 216,000 hours of use

Rys. 3. Wyznaczenie temperatury przejścia w stan kruchy dla elementów złącza spawanego (MR1 oraz S) - próbka 1 po 216000 h eksploatacji 


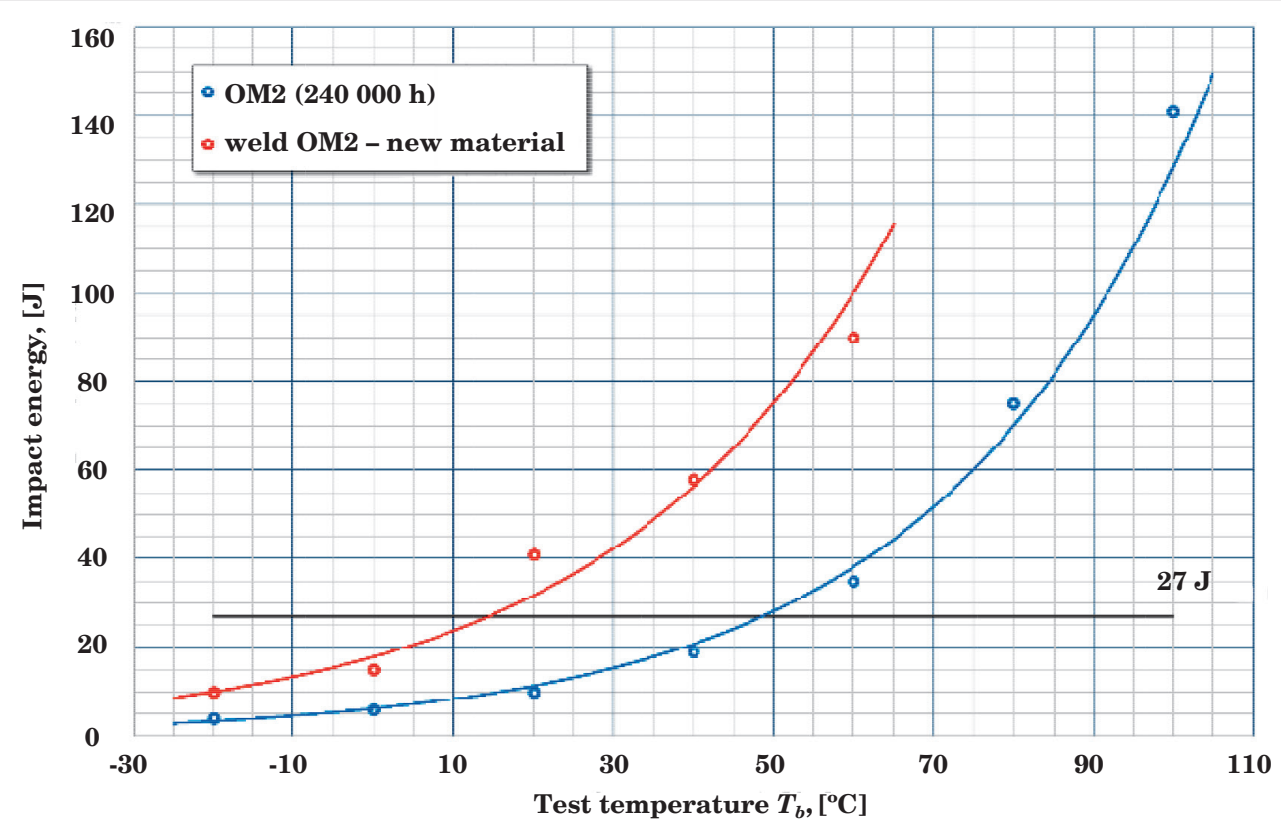

Fig. 4. Determination of the brittle state transition temperature for welded joint components (OM1 and W) - sample 2 after $\mathbf{2 4 0 , 0 0 0}$ hours of use

Rys. 4. Wyznaczenie temperatury przejścia w stan kruchy dla elementów złącza spawanego (MR1 oraz S) - próbka 2 po 240000 h eksploatacji

than in material 1 . The analysed repair joints have different durability margins - up to 116,000 hours for material 1 and only 28,000 hours for material 2 . However, the determined life would be achievable under certain conditions. One of the most important of them would be to observe operating parameters, especially temperature. Its increase by $10^{\circ} \mathrm{C}$ may reduce the material's durability by more than a half (if material 1 is used). Another condition is the system of clamps and supports adequately compensating thermal elongation and preventing excessive material stress. Another important factor is adherence to the optimal heating and cooling rates during start-ups and stops, especially during emergency stops.

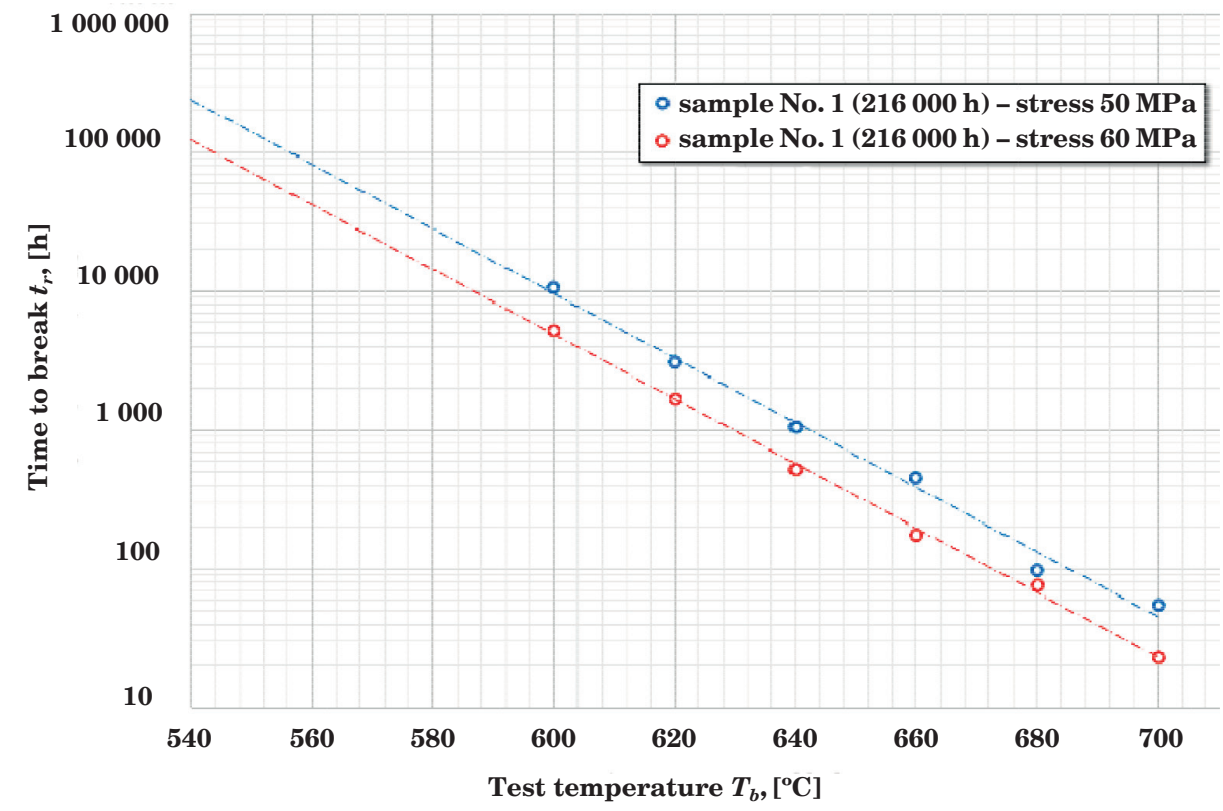

Fig. 5. Dependence of time to break in shortened creep tests of the repair welded joint made of steel 13HMF (material after use + material as delivered) marked as 1 given in the form of the relation $\log t_{z}=\mathbf{f}\left(T_{b}\right)$ at $\sigma_{b 1}=50 \mathrm{MPa}$ and $\sigma_{b 2}=60 \mathrm{MPa}$

Rys. 5. Zależność czasu do zerwania w skróconych próbach pełzania naprawczego złącza spawanego ze stali $13 H M F$ (materiał po eksploatacji + materiał w stanie dostawy) ozn. 1 przedstawiona w postaci zależności log $t_{z}=f\left(T_{b}\right)$ przy $\sigma_{b 1}=50$ MPa oraz $\sigma_{b 2}=60 \mathrm{MPa}$ 


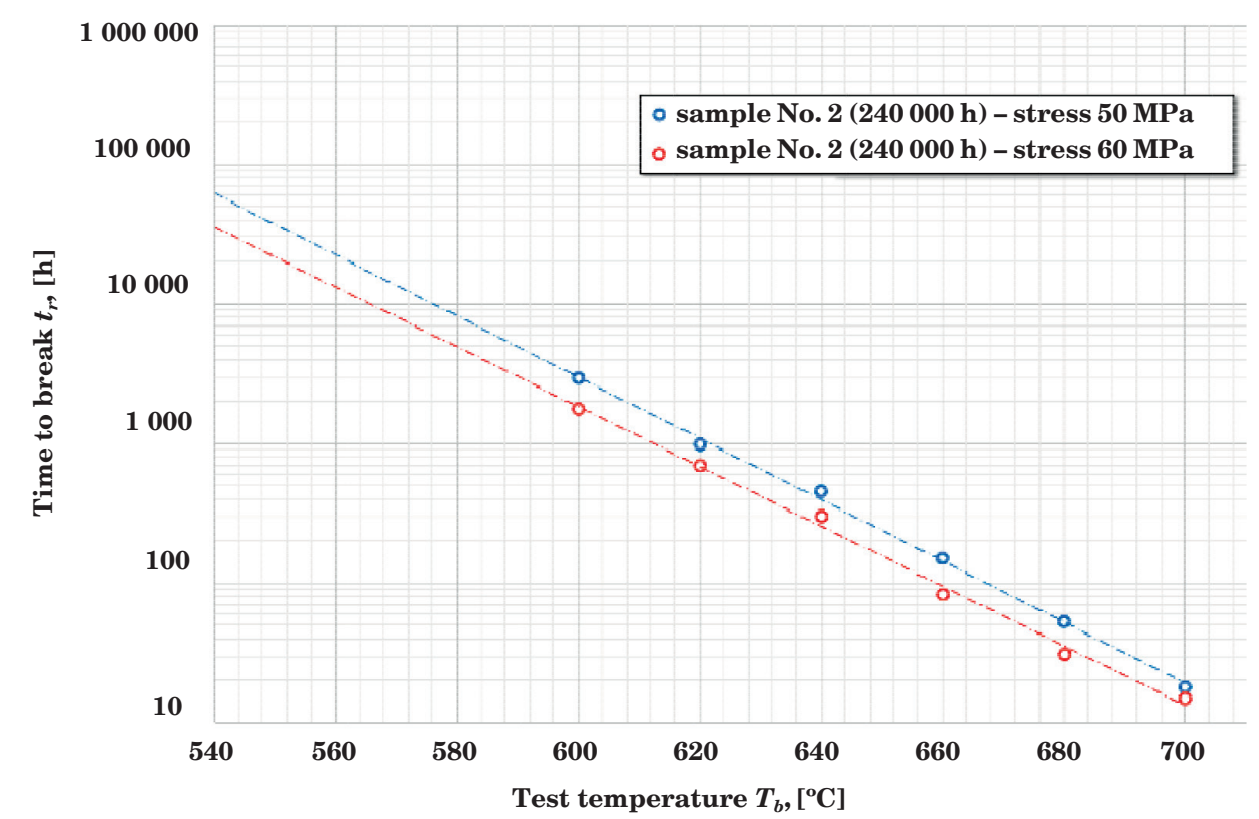

Fig. 6. Dependence of time to break in shortened creep tests of the repair welded joint made of steel 13HMF (material after use + material as delivered) marked as 2 given in the form of the relation $\log t_{z}=\mathrm{f}\left(\mathrm{T}_{b}\right)$ at $\sigma_{b 1}=50 \mathrm{MPa}$ and $\sigma_{b 2}=60 \mathrm{MPa}$ Rys. 6. Zależność czasu do zerwania w skróconych próbach pełzania naprawczego złącza spawanego ze stali 13HMF (materiał po eksploatacji + materiał w stanie dostawy) ozn. 2 przedstawiona w postaci zależności $\log t_{z}=f\left(T_{b}\right)$ przy $\sigma_{b 1}=50 \mathrm{MPa}$ oraz $\sigma_{b 2}=60 \mathrm{MPa}$

Table 6. Residual life and available residual life determined on the basis of short creep tests

Tabela 6. Wyznaczona na podstawie skróconych prób pełzania trwałość resztkowa i rozporządzalna trwałość resztkowa

\begin{tabular}{|c|c|c|c|c|}
\hline \multirow{2}{*}{ Designation } & \multirow{2}{*}{$\begin{array}{l}\text { Assumed operating } \\
\text { stress } \sigma_{r}[\mathrm{MPa}]\end{array}$} & \multirow{2}{*}{$\begin{array}{l}\text { Assumed temperature } \\
\text { of further use } T_{r}\left[{ }^{\circ} \mathrm{C}\right]\end{array}$} & \multicolumn{2}{|c|}{ Estimated life [h] } \\
\hline & & & residual & available \\
\hline \multirow{2}{*}{ Repair joint des. 1} & 50 & 540 & 210,000 & 116,000 \\
\hline & 60 & 540 & 100,000 & 55,000 \\
\hline \multirow{2}{*}{ Repair joint des. 2} & 50 & 540 & 50,000 & 28,000 \\
\hline & 60 & 540 & 35,000 & 19,000 \\
\hline
\end{tabular}

\section{SUMMARY}

The tests performed on repair welded joints presented in this paper allowed to assess the degree of degradation of materials and their suitability to be repaired by welding. The degree of degradation of the material structure significantly affects the further usefulness of components subjected to long-term use in creep conditions. Diversified operating conditions and history of use have a significant impact on the degree of wear, and what is very important, on steam pipelines subjected to use beyond the design operating time.

While the residual life of main materials of steam pipelines subjected to use beyond the design time is optimistic with the proper state of the structure, the durability of repair welded joints may not be optimistic. In the case of the tested materials, with a material wear rate of about 0.4 after 240,000 hours of operation, the residual life of the repair joint in the creep test is only 28,000 hours. Therefore, repairing such a pipeline may prove to be completely unprofitable in a situation when further long-term operation of the power unit is planned.
Loss of durability of pressure elements is usually caused by their incorrect use, often in connection with structural defects. It turns out, however, that also repair processes requiring welding of materials affect it in a very significant way.

Diagnostics should quickly detect causes, the elimination or mitigation of which significantly influences the extension of service life, and verify whether the component requiring repair is useful for this and whether this repair is economically justified from the point of view of further operational plans of the equipment.

The results of the research included in the paper were obtained as part of research co-financed by the National Centre for Research and Development under agreement No. NR PBS/B5/42 /2015 - Project: Methodology, evaluation and prognosis of operation beyond the design operating time of welded joints of pressure elements of power boilers. 


\section{REFERENCES}

[1] A. Hernas, J. Dobrzański. Trwałość $i$ niszczenie elementów kotłów i turbin parowych. Gliwice: Wydawnictwo Politechniki Śląskiej, 2003.

[2] J. Dobrzański. Materiałoznawcza interpretacja trwałości stali dla energetyki, Ed. 3. Gliwice: Open Acces Library, 2011.

[3] A. Jasiński. System diagnostyczny jako sposób na wydłużenie czasu bezpiecznej eksploatacji rurociągów parowych. Ener getyka, 2012, 65 (9).

[4] M. Kwiecień, A. Goławski. Pełzanie jako zjawisko ograniczające długotrwałą eksploatację rurociągów parowych. Ener getyka, 2013, 66 (7).

[5] A. Jasiński. Modelowanie rozkładu naprężeń w systemie diagnostycznym rurociągów pracujących w warunkach pełzania. Energetyka, 2012, 65 (2)

[6] A. Jasiński. Wydłużona eksploatacja krajowych bloków energetycznych - szanse i zagrożenia. Energetyka, 2013, 66 (7).

[7] A. Jasiński. Diagnostyka jako element planowania. Chemia Przemystowa, 2012, 2.

[8] A. Zieliński, J. Dobrzański. Ocena stanu i przydatności do dalszej pracy materiału rurociągów parowych eksploatowanych powyżej obliczeniowego czasu pracy. Prace Intytutu Metalurgii Zelaza, 2013, 65 (3), p. 42-55.

[9] A. Jasiński. Wymogi UDT stawiane urządzeniom ciśnieniowym eksploatowanym ponad obliczeniowy czas pracy. Nowa Energia, 2013, 5-6.

[10] A. Zieliński, M. Kwiecień. Ocena stanu i przydatności do dalszej pracy rurociągów parowych z niskostopowych stali Cr-Mo i Cr-Mo-V eksploatowanych powyżej 200 tys. godzin pracy. Energetyka, 2015, 68 (9), p. 590-596.

[11] A. Jasiński. Jak typować elementy do badań w przypadku rurociągów wysokoprężnych. Energetyka, 2015, 68 (9).
[12] A. Jasiński. Wpływ długotrwałej eksploatacji na własności wytrzymałościowe i dalszą przydatność eksploatacyjną materiału głównych rurociągów parowych bloków typu 200 MW. Dozór Techniczny, 2014, 3.

[13] Polish Committee for Standardisation. PN-H-74252:1998. Rury stalowe bez szwu kotłowe. Warszawa: PKN, 1998.

[14] Polish Committee for Standardisation. PN-EN 10216-2:2014. Rury stalowe bez szwu do zastosowań ciśnieniowych. Technical conditions of delivery. Section 2: Non-alloy and alloy steel tubes with specified elevated temperature properties. Warszawa: PKN, 2014.

[15] Polish Committee for Standardisation. PN-75/H-84024: 1975. Stal do pracy przy podwyższonych temperaturach - Gatunki. Warszawa: PKN, 1975.

[16] ENERGOPOMIAR. Sp. z o.o. Instrukcja badań $i$ oceny stanu technicznego rurociagów pracujacych $w$ warunkach petzania - opracowanie. Gliwice, 2012 [non-published].

[17] A. Zieliński. Metodyka, ocena $i$ prognoza eksploatacji powyżej obliczeniowego czasu pracy złaczy spawanych elementów ciśnieniowych kotłów energetycznych, IMŻ report No. PB0006/2015. Gliwice, 2015 [non-published].

[18] A. Zieliński, A. Jasiński. Trwałość resztkowa materiału rurociągów parowych, pracujących w układzie kolektorowym, po przepracowaniu obliczeniowego czasu pracy. Energetyka, 2016,69 (3), p. 165-170.

[19] M. Sroka, A. Zieliński, M. Dziuba-Kałuża, M. Kremzer, M. Macek, A. Jasiński. Assessment of the Residual Life of Steam Pipeline Material beyond the Computational Working Time. Metals, 2017, 7 (3), p. 82. 